Acta vet. scand. $1981,22,344-354$.

From the Department of Animal Husbandry and the Department of Veterinary Medicine, University of Helsinki, Finland.

\title{
THE EFFECTS OF SUGAR ALCOHOLS ON METABOLISM OF GROWING PIGS
}

\author{
By \\ Matti Näsi and Eero Tanhuanpää
}

\begin{abstract}
NÄSI, M. and E. TANHUANPÄA: The effects of sugar alcohols on metabolism of growing pigs. Acta vet. scand. 1981, $22,344-354$. - In two experiments of $3 \times 3$ Latin square with growing pigs, the effect was investigated of supplementation of $5 \%$ or $10 \%(2.5 \%$ vs. $5 \%$ DM) polyol mixture and $2.5 \%$ or $5 \%$ of xylitol on digestibility of diet, N-balance, blood clinical-chemical parameters and insulin level in serum. Apparent digestibility of crude protein was lower for the diet with $10 \%$ polyol mixture compared to the control. Sugar alcohols were not found in faeces. Arabinitol, mannitol and rhamnitol were excreted in the urine 25-67\%. Little sorbitol and xylitol were found in urine on diets with polyol mixture 5-10\%. On xylitol diets the pigs did not excrete xylitol in urine. Plasma glucose rose in pigs fed xylitol. Blood total protein and albumin decreased in pigs fed polyol mixture. ALAT-activities were higher for xylitol diets than for the controls. Serum insulin tended to increase in pigs fed polyol mixture $10 \%$ one hour after feeding, and in xylitol feeding two hours after feeding; these values were higher with increasing xylitol inclusion in diet.
\end{abstract}

sugar alcohols; polyol mixture; xylitol; pigs; in s u li n.

Sugar alcohols are utilized efficiently by animals (Touster 1974). In long term feeding experiments with rats it was found that $10 \%$ and $30 \%$ of xylitol in the diet were well tolerated and produced no adverse effects regarding growth, protein efficiency and histopathology of the main organs, and the amounts of xylitol fed were utilized efficiently and could cover the caloric requirement of the animals (Lang 1969).

Xylitol has increased the plasma insulin content in man and dog (Kosaka et al. 1969, Kuzuya et al. 1969). Insulin stimulates muscle protein synthesis and decreases protein breakdown (Jefferson et al. 1977). 
Polyol mixture or sugar alcohols, a by-product of xylitol production from xylane-containing material, has proved to be a good supplement in piglet's creep feed and it has obviously antimicrobial effects leading to decreased mortality and incidence of diarrhoea, and to improved feed conversion efficiency ( $N a ̈ s i$ \& Alaviuhkola 1980, 1981).

This study is part of a research project directed at the utilization of polyol mixture in the nutrition of domestic animals. The effects of polyol mixture or xylitol on the digestibility of diet, blood profile and serum insulin level were investigated.

\section{MATERIALS AND METHODS}

Digestibility trials were carried out with six castrated Landrace pigs weighing $39-75 \mathrm{~kg}$. The experiment was performed using a total collection method as two $3 \times 3$ Latin squares with polyol mixture or xylitol supplementations. Transition period between diets was 5 days, preliminary period 7 days and collection period 7 days.

The basic feed was barley milled with a $3 \mathrm{~mm}$ sieve, supplemented with $15 \%$ skimmed milk powder and mineral and vitamin mixture 55 g daily. Polyol mixture was added as $5.0 \%$ or $10.0 \%(2.5 \%$ or $5.0 \%$ of dry matter) of the ration. Xylitol inclusion was $2.5 \%$ or $5.0 \%$ of the ration. The control supplement was wheat starch $5.0 \%$ or $2.5 \%$. The daily rations in different periods were 1.8, 2.4 and $2.8 \mathrm{~kg}$ feed. Feeding was made daily as liquid feed. Water was given after feeding. Feed orts were collected and subtracted from given feed.

The collection of faeces and urine was made twice daily, and relative samples were taken and stored frozen until analysed. Analyses were made according to Paloheimo (1969). Sugar alcohol composition of the polyol mixture and of faeces and urine was made by a gas chromatograph (Carlo Erba).

The blood samples were collected by syringe from the anterior vena cava before feeding, $1 \mathrm{~h}, 2 \mathrm{~h}$ and $4 \mathrm{~h}$ after feeding. The pigs were restrained with a nose sling in standing position.

The samples for chemical analyses were transferred to heparinized test tubes, and those intended for haematological determinations to EDTA tubes. Blood serum was used for insulin determination after blood standing for $8 \mathrm{~h}$. The heparinized tubes were immediately centrifuged and the plasma decanted. 
The determination of glucose was made immediately. Serum and plasma were stored deep frozen until analysed. Plasma glucose was determined by O-toluidine-method (Hyvärinen \& Nikkilä 1962). Other blood clinical-chemical parameters and blood enzymes were determined by an Auto Analyzer GILFORD 3500 with the commercial adapted reagent kits according to the standard methods of the Committee on Enzymes of the Scandinavian Society for Clinical Chemistry and Clinical Physiology (1974, 1976), and minerals and trace elements by an atomic absorption spectrophotometer (Varian Techtron AA 1000).

Plasma insulin was measured by a modification of the method of Basset \& Thorburn (1971) using radioimmunoassay. The determinations were performed at the University of Aberdeen.

\section{RESULTS AND DISCUSSION}

The daily intake of polyol mixture was $47-73 \mathrm{~g}$ DM of the $5 \%$ inclusion and 94-145 g DM of the $10 \%$ inclusion in diet. Xylitol intakes were $45-70 \mathrm{~g}$ of the $2.5 \%$ inclusion and $90-$ $140 \mathrm{~g}$ of the $5 \%$ inclusion daily during different periods. Intakes corresponded 1.1 or $2.2 \mathrm{~g}$ of sugar alcohols per $\mathrm{kg}$ live weight. The dry matter percentage of polyol mixture was $52.1 \%$ and it had the following composition of sugar alcohols (\% in dry matter): arabinitol 16.6, erythritol 3.2, galactitol 2.4, glycerol 2.7, mannitol 11.3, rhamnitol 4.9, sorbitol 14.7, xylitol 27.1, glucose 10.0 and other reducing matter $7.1 \%$.

Digestibility coefficients for the diet with and without the addition of polyol mixture or xylitol are presented in Table 1 . Apparent digestibility of crude protein was lower $(P<0.05)$ in diet supplement with $10 \%$ of polyol mixture. The same trend was noticed also in diet supplemented with $5 \%$ xylitol $(\mathrm{P}>$ $0.05)$. Digestibility of ether extract was also lower $(P>0.05)$ in diets supplemented with sugar alcohols. Fermentation in the colon may be increased with diets supplemented with sugar alcohols due to the passage of polyols to the large intestine and thus the apparent digestibility of crude protein and crude fat was decreased. Digestibility trials with dairy cows showed lower digestibility of crude protein and ether extract of the diet supplemented with polyol beat pulp but improved digestibility of NFE (Tuori \& Poutiainen 1977). 
T a b l e 1. Digestibility coefficients, $\mathrm{N}$-balance and biological values for diets with and without the addition of polyol mixture or xylitol.

\begin{tabular}{|c|c|c|c|c|c|c|c|c|c|c|c|c|}
\hline & \multicolumn{6}{|c|}{ Polyol mixture } & \multicolumn{6}{|c|}{ Xylitol } \\
\hline & \multicolumn{2}{|c|}{ Control } & \multicolumn{2}{|c|}{$5.0 \%$ polyols } & \multicolumn{2}{|c|}{$10.0 \%$ polyols } & \multicolumn{2}{|c|}{ Control } & \multicolumn{2}{|c|}{$2.5 \%$ xylitol } & \multicolumn{2}{|c|}{$5.0 \%$ xylitol } \\
\hline & $\overline{\mathbf{x}}$ & $\mathbf{s}$ & $\overline{\mathbf{x}}$ & $\mathbf{s}$ & $\overline{\mathbf{x}}$ & $\mathbf{s}$ & $\overline{\mathbf{x}}$ & $\mathbf{s}$ & $\overline{\mathbf{x}}$ & $\mathbf{s}$ & $\overline{\mathbf{x}}$ & $\mathbf{s}$ \\
\hline Dry matter & 84.1 & 1.0 & 84.3 & 1.2 & 83.5 & 1.2 & 83.6 & 1.3 & 84.1 & 1.1 & 84.0 & 0.7 \\
\hline Ash & 56.1 & 2.6 & 56.7 & 5.3 & 55.1 & 5.0 & 54.5 & 4.2 & 57.9 & 1.6 & 54.6 & 1.4 \\
\hline Organic matter & 85.6 & 0.8 & 85.8 & 0.8 & 85.0 & 0.8 & 85.3 & 1.0 & 85.3 & 0.9 & 85.4 & 0.7 \\
\hline Crude protein & $80.8^{a}$ & 1.0 & $80.3^{a}$ & 2.3 & $79.2 b$ & 2.9 & 80.5 & 2.7 & 80.7 & 3.0 & 79.0 & 2.1 \\
\hline Ether extract & 74.4 & 3.8 & 70.8 & 8.9 & 71.5 & 3.3 & 71.9 & 6.4 & 67.5 & 19.3 & 68.5 & 8.8 \\
\hline Crude fibre & 20.4 & 3.0 & 21.8 & 6.3 & 19.8 & 7.5 & 19.8 & 9.6 & 18.7 & 6.4 & 22.5 & 7.4 \\
\hline N F E & 90.7 & 0.6 & 91.0 & 0.3 & 90.4 & 0.4 & 90.4 & 0.6 & 90.9 & 0.2 & 91.0 & 0.3 \\
\hline N-bala & 24.9 & 4.3 & 25.2 & 5.3 & 23.5 & 4.7 & 24.0 & 5.1 & 24.0 & 3.5 & 23.5 & 2.3 \\
\hline Biological value & 76.1 & 2.6 & 76.7 & 3.1 & 74.4 & 4.8 & 74.1 & 2.5 & 74.6 & 5.1 & 75.2 & 7.1 \\
\hline
\end{tabular}

means with different letters were significantly different: $a, b(P<0.05)$

Nitrogen balances in diets supplemented with $10 \%$ of polyol mixture or $5 \%$ of xylitol were a little decreased, but the differences were not significant $(P>0.05)$. Protein biological value in the diet supplemented with $10 \%$ polyol mixture was decreased, but opposite to this in the diet with $5 \%$ of xylitol the value was higher than the control one.

Sugar alcohols were not found in faeces of pigs fed polyol mixture or xylitol. Table 2 presents the excretion of sugar alcohols in the urine as the percentage of intake in pigs receiving polyol mixture 5 or $10 \%$ in diet.

Arabinitol, mannitol and rhamnitol were excreted in urine, 25-67\% of the intake. Little sorbitol and xylitol were found. Pigs fed diets including xylitol did not excrete xylitol in the

T a b l e 2. Excretion of sugar alcohols in the urine (percentage of intake).

\begin{tabular}{lcc}
\hline $\begin{array}{l}\text { Sugar } \\
\text { alcohol }\end{array}$ & $\begin{array}{c}5.0 \% \text { polyol } \\
\text { mixture }\end{array}$ & $\begin{array}{c}10.0 \% \text { polyol } \\
\text { mixture }\end{array}$ \\
\hline Arabinitol & 39.8 & 38.4 \\
Erythritol & 0 & 0 \\
Galactitol & 0 & 0 \\
Mannitol & 67.3 & 44.2 \\
Rhamnitol & 33.7 & 24.5 \\
Sorbitol & 6.4 & 6.0 \\
Xylitol & 0.6 & 0.9 \\
\hline
\end{tabular}


urine. Tuori (1979) found with dairy cows that only $0.7 \%$ of the total intake of polyols were secreted in the urine, but nothing in the faeces. Animals can utilize rather large doses of xylitol efficiently. Humans e.g. apparently can use several hundred grams of xylitol per day. Little xylitol is found in the urine after large doses are administered (Lang 1969). McCormick \& Touster (1967) found with rats arabinitol to be excreted in the urine $36-38 \%$. Mannitol and sorbitol were also detected in human urine by Ingram et al. (1971).

The data of blood composition of pigs fed sugar alcohols is presented in Table 3. Blood haematocrit and haemoglobin were decreased in pigs fed sugar alcohols compared to controls but not significantly $(P>0.05)$. Plasma glucose rose significantly $(P<0.05)$ in pigs fed xylitol. Urea-N in blood was decreased a little in pigs fed sugar alcohols. Blood total protein decreased significantly $(P<0.05)$ in pigs fed polyol mixture. The same was also found for the albumin concentration. Crude protein digestibility was also decreased in polyol diets. In xylitol diets the albumin concentration was, reverse to polyol mixture, significantly $(P<0.05)$ higher compared to the control one. Creatinine in plasma was decreased in polyol-supplementation of $10 \%(\mathrm{P}<0.01)$ but opposite to this the values were higher on xylitol-feeding. The total bilirubin was increased $(P>0.05)$ in pigs fed sugar alcohols and this may have a connection to the decreased level of haemoglobin and haematocrit.

There were only small differences in contents of minerals in the plasma of pigs fed sugar alcohols. Only the sodium content was increased in the sugar alcohol diets. Plasma potassium was decreased in xylitol feeding $(P<0.01)$. Haematological and blood chemical values were in general in accordance with values given by Glawishnig et al. (1977), Näsi et al. (1978) and Schmidt (1979) indicating no detrimental effects of sugar alcohols in pig diets.

Alkaline phosphate (AP) values were quite similar among treatments. Values were high compared to those presented by Flückiger (1977) and Schmidt (1979). Raised AP-values in serum are found whenever there is intensified osteoplast activity. AP-values in the milk of sows fed polyol mixture did not differ from control ones, only the values in colostrum were little increased (Mäkinen et al. 1981). Alanine and asparate transferase (ALAT and ASAT) activities were increased in plasma of pigs 


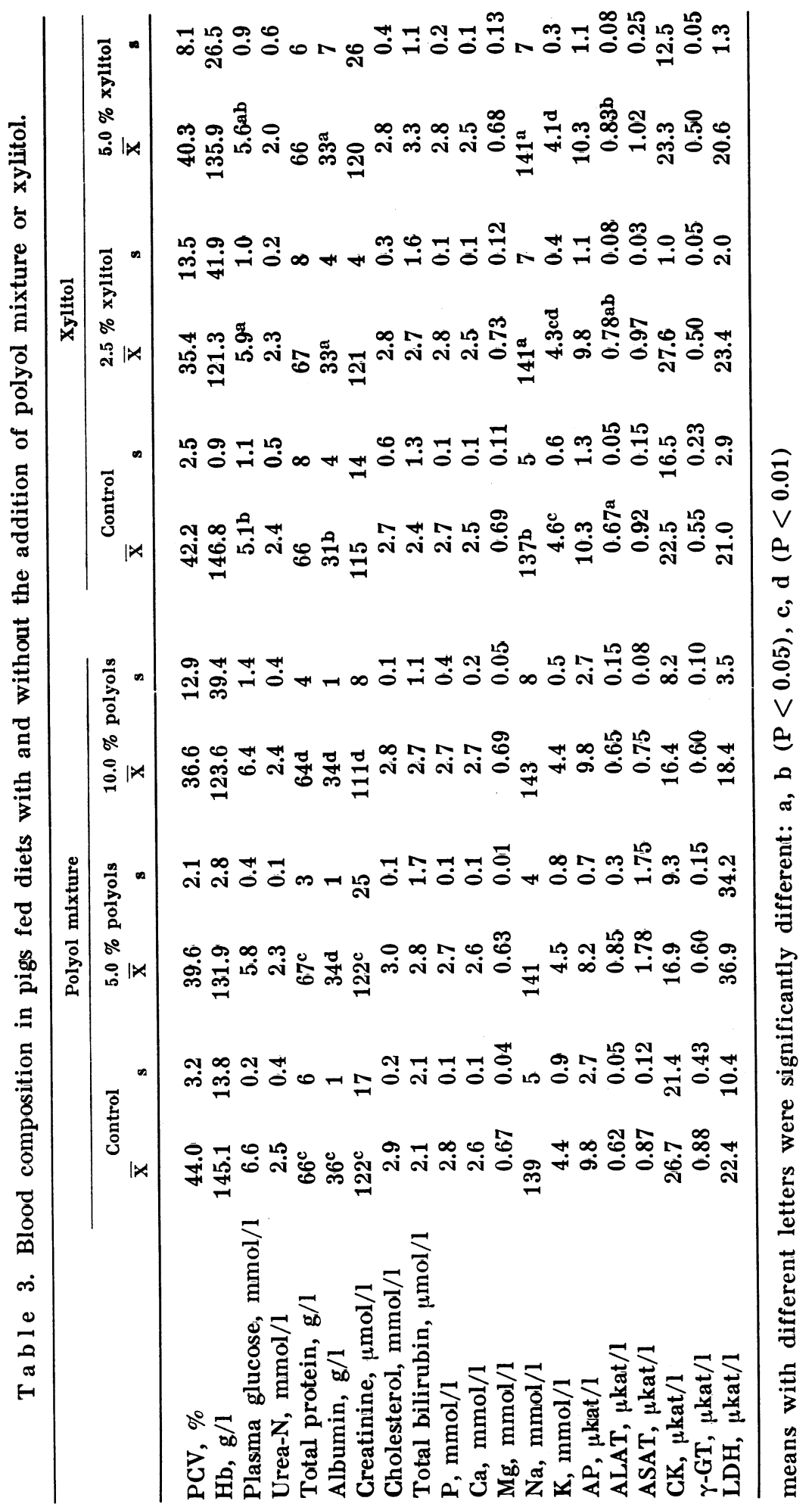


fed sugar alcohols. ALAT values were increased significantly $(P<0.05)$ with increasing xylitol inclusion. Higher ALAT values indicate damage of liver cells (Schmidt 1979). Flückiger (1977) assumes that ASAT is not so sensitive in pigs and ALAT has no significance in pigs. Creatine kinase $(\mathrm{CK})$ values varied widely among treatments. A rise in serum CK-activity is accordingly only to be expected when there is damage to skeletal or heart muscle. In the case of muscular dystrophy very high values are also found. The values of CK-activity found here were higher than those presented by Glawischnig et al. (1977). $\gamma$-glutamyl transferase $(\gamma-\mathrm{GT})$ values were lower in pigs fed sugar alcohols compared to the control ones. One pig on control treatment had a high value of $1.4 \mu \mathrm{kat} / \mathrm{l}$, which indicated damage in liver cells. Lactate dehydrogenase (LDH) values varied widely within animal and treatments. Values were higher than reported as normal (Flückiger 1977, Schmidt 1979). LDH is sensitive for muscle damage.

Intracellular enzymes measured showed that there were differences in activities and values in sugar alcohol diets indicated slight cell damages of liver and muscle. This may be attributed to changes of diets and short periods of adaptation to sugar alcohols. The pigs in the performed trial were observed to be clinically healthy.

The concentration of insulin in serum of pigs fed polyol mixture or xylitol is shown in Tables 4 and 5 . Variation in insulin concentrations was quite wide and thus differences between treatments were small. The insulin concentration on xylitol feeding tended to increase and values $2 \mathrm{~h}$ after feeding were higher $(P>0.05)$ than the control ones. Also $5 \%$ xylitol supplement led to a higher values than $2.5 \%$ of xylitol. Insulin for the diet supplemented with $10 \%$ of polyol mixture was higher

T a b l e 4. Serum concentration of insulin in pigs fed diets with and without the addition of polyol mixture $(\mu \mathrm{U} / \mathrm{ml})$.

\begin{tabular}{|c|c|c|c|c|c|c|}
\hline \multirow[t]{2}{*}{ Sampling time } & \multicolumn{2}{|c|}{ Control diet } & \multicolumn{2}{|c|}{$5.0 \%$ polyols } & \multicolumn{2}{|c|}{$10.0 \%$ polyols } \\
\hline & $\overline{\mathbf{x}}$ & $\mathbf{s}$ & $\overline{\mathbf{x}}$ & $\mathbf{s}$ & $\overline{\mathbf{x}}$ & $\mathbf{s}$ \\
\hline Before feeding & 65 & 17 & 86 & 29 & 89 & 65 \\
\hline $1 \mathrm{~h}$ after feeding & 28 & 4 & 30 & 21 & 48 & 37 \\
\hline $2 \mathrm{~h}$ after feeding & 162 & 17 & 141 & 37 & 161 & 66 \\
\hline $4 \mathrm{~h}$ after feeding & 90 & 13 & 116 & 52 & 96 & 7 \\
\hline
\end{tabular}


T a b l e 5. Serum concentration of insulin in pigs fed diets with and without the addition of xylitol $(\mu \mathrm{U} / \mathrm{ml})$.

\begin{tabular}{lrrrrrrr}
\hline Sampling time & \multicolumn{3}{c}{ Control diet } & \multicolumn{2}{c}{$2.5 \%$ xylitol } & \multicolumn{3}{c}{$5.0 \%$ xylitol } \\
& $\bar{x}$ & $\mathrm{~s}$ & $\overline{\mathrm{x}}$ & $\mathrm{s}$ & $\overline{\mathrm{x}}$ & $\mathrm{s}$ \\
\hline Before feeding & 107 & 53 & 90 & 60 & 84 & 22 \\
1 h after feeding & 33 & 18 & 33 & 14 & 26 & 13 \\
2 h after feeding & 155 & 13 & 175 & 153 & 201 & 106 \\
4 h after feeding & 94 & 81 & 80 & 21 & 95 & 44 \\
\hline
\end{tabular}

$1 \mathrm{~h}$ after feeding compared to other treatments. Ehrensvärd et al. (1978) reported an average insulin content in blood of $75.4 \pm 32.6$ $\mu \mathrm{U} / \mathrm{ml}$ and that it was correlated with the live weight of the pig and the intake of carbohydrates. The peak of insulin content in blood was found to be between 40 and 60 min after feeding in piglets (Berschauer et al. 1979b). The values obtained were in good accordance with results reported in the literature of the insulin concentration in blood of pigs (Fuller et al. 1977, Ehrensvärd et al. 1978, Berschauer et al. 1979a,b, Ensinger 1979).

Intravenous administration of xylitol has increased plasma insulin concentrations significantly and the values were 2.5 times higher than those following glucose administration (Kuzuya et al. 1969, Kosaka 1969). Oral administration of $1.0 \mathrm{~g} / \mathrm{kg}$ of xylitol also produced a greater hyperinsulemia than $1.0 \mathrm{~g} / \mathrm{kg}$ of glucose and a consistent hypoglycemia in dogs (Kuzuya et al. 1969). Xylitol is known to enter the pentose-phosphate pathway via $\mathrm{D}$-xylulose-5-phosphate, thus sharing some common metabolic processes with glucose.

The protein metabolism is influenced by hormones. Insulin stimulates muscle protein synthesis, increasing amino acid and energy supply and peptide chain initiation (Rannels et al. 1976, Jefferson et al. 1977). Some in vitro experiments indicate that insulin inhibits protein catabolism in muscles (Jefferson et al. 1974, Fulks et al. 1975). By increasing the insulin levels within the physiological range, $\mathrm{N}$-retention could be increased (Fuller et al. 1977).

\section{ACKNOWLEDGEMENTS}

The authors are indebted to Mr. Timo Laitinen for technical assistance, to Dr. J. Chesworth, University of Aberdeen for insulin determinations, and to Farmos Group, Agricultural Division for financial support. 


\section{REFERENCES}

Basset, J. H. \& G. D. Thorburn: The regulation of insulin secretion by the ovine foetus in utero. J. Endocr. 1971, 50, 59-74.

Berschauer, F., U. Ehrensvärd, G. Gaus \& K. H. Menke: Einfluss eines isokalorischen Austausches von Kohlenhydratenergie gegen Fettenenergie bei Ferkeln auf den Proteinansatz und auf die Gehalte an Harnstoff, Insulin und Glucose im Blut. (Effect of change of a isocaloric carbohydrate energy to fat energy with piglets on protein utilization and urea, insulin and glucose content in blood). Z. Tierphysiol., Tierernährg. u. Futtermittelkde 1979a, 41, 35-36.

Berschauer, F., U. Ehrensvärd \& K. H. Menke: Zur Wirksamkeit von Olaquindox und Chlortetracyclin in der Ferkelaufzucht. (On the efficiency of olaquindox and chlortetracycline on growing piglets). Z. Tierphysiol., Tierernährg. u. Futtermittelkde 1979b, 41, 280-292.

Committee on Enzymes of the Scandinavian Society for Clinical Chemistry and Clinical Physiology: Recommended methods for the determination of four enzymes in blood. Scand. J. clin. Lab. Invest. $1974,33,291-306$.

Committee on Enzymes of the Scandinavian Society for Clinical Chemistry and Clinical Physiology: Recommended methods for the determination of gamma-glutamyltransferase in blood. Scand. J. clin. Lab. Invest. 1976, 36, 119-126.

Ehrensvärd, U., F. Berschaurer, G. Gaus \& K. H. Menke: Einfluss der Rationszusammensetzung auf die Blut-Glucose und InsulinSpiegel beim Schwein. (Effect of ration composition on blood glucose and insulin level in pigs). Z. Tierphysiol., Tierernährg. u. Futtermittelkde 1978, 40, 115-117.

Ensinger, U., E. Rogdarkis \& V. H. Faber: Glukosetoleranz und Insulinsekretion bei Pietarians und Edelschwein. (Glucose tolerance and insulin secretion in Pietarian and Large white pigs). Z. Tierphysiol., Tierernährg. u. Futtermittelkde 1979, 41, 301-309.

Flückiger, M.: Enzymaktivitäten in Serum und Organen des jungen Schweines. 1. Mitteilung, Bestimmung der Normwerte, Beurteilung der klinischen Verwendbarkeit und Vergleicht mit Angaben für den Menschen. (Enzyme activities in serum and organs of young pigs). Zbl. Vet. Med. A. 1977, 24, 195-204.

Fulks, R. M., B. Li \& A. L. Goldberg: Effects of insulin, glucose and amino acids on protein turnover in rat diaphragm. J. biol. Chem. 1975, 250, 290-298.

Fuller, M. F., T. E. C. Weekes, A. Cadenhead \& J. B. Bruce: The proteinsparing effect of carbohydrate. 2. The role of insulin. Brit. J. Nutr. $1977,38,489-496$.

Glawischnig, E., G. Schlerka, W. Schuller \& W. Baumgartner: Arbeitswerte in der Laboratoriumsdiagnostik beim Schwein. (Working values for laboratory diagnosis in pigs). Wien. tierärztl. Mschr. $1977,64,341-346$. 
Hyvärinen, A. \& E. Nikkilä: Specific determination of blood glucose with O-toluidine. Clin. chim. Acta 1962, 7, 140-143.

Jefferson, L. S., J.B. Li \& S.R. Rannels: Regulation by insulin of amino acid release and protein turnover in the perfused rat hemicorpus. J. biol. Chem. 1977, 252, 1476-1483.

Jefferson, L. S., D. E. Rannels, B. L. Munger \& H. E. Morgan: Insulin in the regulation of protein turnover in heart and skeletal muscle. Fed. Proc. 1974, 33, 1098-1104.

Kosaka, $K$.: Stimulation of insulin secretion by xylitol administration. Int. Symp. on Metab., Physiol. and clinical use of Pentoses and Pentitols. 1969, pp. 212-225.

Kuzuya, T., Y. Kanazawa \& K. Kosaka: Stimulation of insulin secretion by xylitol in dogs. Endocrinology 1969, 84, 200-207.

Lang, $K$.: Utilization of xylitol in animals and man. Int. Symp. on Metab., Physiol. and clinical use of Pentoses and Pentitols. 1969, pp. $151-156$.

McCormick, D. B. \& O. Touster: The conversion in vivo of xylitol to glucogen via the pentose phosphate pathway. J. biol. Chem. 1957, 229, 451-461.

Mäkinen, K. K., J. M. Näsi \& T. Alaviuhkola: On the composition of sow milk during polyol feeding. Nutr. Rep. Internat. 1981, 18, (in press).

Näsi, M. \& T. Alaviuhkola: Polyol mixture supplementation in the diet of breeding sows and piglets. J. sci. agric. Soc. Finl. 1980, 52, $50-58$.

Näsi, M. \& T. Alaviuhkola: Polyol mixture supplementation as a sweetener and/or feed additive in the diet of piglets. J. sci. agric. Soc. Finl. 1981, 53, 57-63.

Näsi, M., H. Saloniemi \& K. Kallela: Hematological and blood chemical data of pigs fed various amounts of mink manure. Acta vet. scand. 1978, 19, 84-92.

Paloheimo, L.: Weender Analyse. Handb. Tierernährg. 1969, I, 164171.

Rannels, D. E., R. Kao \& H. E. Morgan: Effect of insulin on protein turnover in heart muscle. J. biol. Chem. 1975, 250, 1694-1701.

Schmidt, M.: Laboratory testing in veterinary medicine. Diagnosis and clinical monitoring. Boehringer Mannheim GmbH. 1979, 130 pp.

Touster, O.: The metabolism of polyols. In Sugars in Nutrition. Sipple, H. L. and K. W. McNutt (eds.). New York 1974, pp. 229-239.

Tuori, M.: A polyol mixture and molasses-treated beet pulp in the silage based diet of dairy cows. III. The effect on the utilization of minerals. J. sci. agric. Soc. Finl. 1979, 51, 528-535.

Tuori, M. \& E. Poutiainen: A polyol mixture or molasses treated beet pulp in the silage based diet of dairy cows. I. The effect on the feed utilization, milk yield and blood values. J. sci. agric. Soc. Finl. 1977, 49, 315-329. 


\section{SAMMANFATTNING}

Effekten av sockeralkoholer på ämnesomsättningen hos växande grisar.

I två försök med växande grisar med en utfodring enligt $3 \times 3$ latinsk kvadrat undersöktes effekten av en tillsats av $5 \%$ eller $10 \%$ (2.5 eller $10 \%$ DM) polyol-blandning, samt $2.5 \%$ eller $5 \%$ xylitol på fodrets smältbarhet, N-balansen, klinisk-kemiska blodparametrar och insulinstatus i serum. Råproteinets smältbarhet verkade vara lägre med ett foder innehållande $10 \%$ polyol-blandning än med kontrollfodret. Sockeralkoholer kunde inte påvisas avföringen. Arabinitol, mannitol och rhamnitol utsöndrades till 25-67\% med urinen. Endast litet sorbitol och xylitol kunde påvisas i urinen vid en diet med en 5-10\% polyol-blandning. Vid en xylitol-diet utsöndrade grisarna inget xylitol med urinen. Glukos i blodplasma steg hos grisar utfodrade med xylitol. Blodproteinet och -albuminet sjönk hos grisar utfodrade med en polyol-blandning. ALAT-värdena var högre vil xylitol-dieter jämfört med kontrollen. En timme efter utfodring med en $10 \%$ polyolblandning visade insulinet $i$ serum en tendens att öka. Vid xylitolutfodring var dessa värden två timmar efter utfodringen allt högre, följande ökande tillsatser av xylitol i fodret.

(Received May 4, 1981).

Reprints may be requested from: Matti Näsi, the Department of Animal Husbandry, University of Helsinki, 00710 Helsinki 71, Finland. 